\title{
Habitat complexity explains species-specific occupancy but not species richness in a Western Australian woodland.
}

Jarrad A. Cousin $^{\mathrm{A}, \mathrm{D}}$ and Ryan D. Phillips ${ }^{\mathrm{B}, \mathrm{C}}$

${ }^{A}$ Centre for Ecosystem Management, School of Natural Sciences, Edith Cowan University, Joondalup WA 6027

${ }^{B}$ Kings Park and Botanic Garden, The Botanic Garden and Parks Authority, West Perth, 6005, Western Australia

${ }^{\mathrm{c}}$ School of Plant Biology, University of Western Australia, Nedlands, 6009, Western Australia

${ }^{\mathrm{D}}$ Corresponding author, present address: School of Environment, Griffith University, Nathan, QLD, 4111; jcousin@graduate.uwa.edu.au

Editorial contact for corresponding author:

Postal address: School of Environment, Griffith University, Nathan, QLD, 4111

Email: jcousin@graduate.uwa.edu.au

Mobile: 0421488840

Abridged title for running head: Influence of habitat complexity on bird species 


\section{Abstract}

Habitat complexity is an important factor governing species richness and habitat selection in birds. The present study examined this relationship in a large Wandoo woodland in Western Australia. Habitat complexity (comprising canopy, shrub, ground vegetation, log and leaf litter cover) and bird species richness was recorded in 48 sites, each approximately three hectares in size. We found no significant correlation of habitat complexity with species richness. We propose the absence of such a relationship results from the resource-poor environment of the woodlands of south-western Australia. The relative scarcity of food resources results in a species richness threshold beyond which there are insufficient niches and resources to support additional species with increasing habitat complexity. Only two species exhibited significant associations with habitat complexity, with the western yellow robin (Eopsaltria griseogularis) occupying sites with higher habitat complexity, and the restless flycatcher (Myiagra inquieta) occupying sites with lower habitat complexity. Although some species may respond specifically to habitat complexity, management of avian biodiversity within Australian woodlands should take into account the potentially greater role that productivity and resource availability plays in influencing species richness, rather than habitat complexity per se. Furthermore, the individual components comprising habitat complexity may be of equal importance in assessing relationship of species richness to overall habitat complexity. 


\section{Introduction}

Avian species diversity and richness in terrestrial habitats is closely associated with habitat structure and floristics. Many researchers suggest that habitat structure rather than floristics is the principal factor governing avian species diversity, whereby habitats with greater structural complexity harbour more abundant resources and afford a greater potential for segregation of available microhabitats (e.g. Hulbert 2004; MacArthur and MacArthur 1961; MacArthur et al. 1962; Willson 1974). This pattern is not restricted to avian communities, with faunal communities as diverse as those of wasps (Lassau and Hochuli 2005), reef fish (Lingo and Szedlmayer 2006) and kelp forest macrofauna (Hauser et al. 2006) increasing in diversity and richness with an increase in habitat complexity. Despite the widespread occurrence of this relationship, the exact mechanism that drives this association is still debated. For example, MacArthur and MacArthur (1961) and Willson (1974) suggest that an increase in foliage height diversity results in an increase in species diversity in response to a greater number of available niches. However, species richness and diversity responses to habitat complexity may be regulated by productivity, such that species richness and diversity responds to the productivity and elevated resources in complex habitats (Hulbert 2004).

Just as habitat structure is an important determinant of species diversity and richness, it is also an important factor contributing to the habitat selection of individual species (e.g., Watson et al. 2004). The association of whole avian communities and individual species with specific habitat structural attributes is influenced by many factors including the provision of adequate resources for foraging and breeding, and shelter from weather, predators and parasites (Hildén 1965). In turn, many factors can alter habitat structural attributes, and thus the appropriateness of habitat for avian communities and individual species, including grazing (Ammon and Stacey 1997; Ludwig et al. 2000; Williams 1990), fire (Coops and Catling 2000) and logging (Willett 2001). An understanding of the habitat complexity thresholds of individual species 
will provide further insight into the factors influencing avian diversity, the reasons for the decline of some woodland species (Ford et al. 2001) and will allow for a more accurate appraisal of the habitat requirements of declining species and the potential effects of continued landuse changes.

The present study was undertaken in the wheatbelt region of Western Australia; an area in which 93\% of the original vegetation has been cleared since the Second World War (Saunders et al. 1985). Wandoo (Eucalyptus wandoo) woodland was preferentially cleared, on account of its association with more productive downslope soils (Coates 1993). As a result of the decline in distribution and abundance of a large number of species associated with Wandoo woodlands in the wheatbelt of Western Australia (Saunders and Curry 1990; Saunders and Ingram 1995), the present study represents an important step to an understanding of the ecological requirements of this community. The aims of the present study were to (i) determine if there was an association between habitat complexity and avian species richness in Wandoo woodland and (ii) to determine whether individual species exhibited habitat complexity thresholds within this woodland.

\section{Materials and methods}

Study area

The study was undertaken 180 km south-east of Perth Western Australia in Dryandra Woodland (324ㄱ'S, $\left.116^{\circ} 58^{\prime} \mathrm{E}\right)$. This 22,000 ha reserve is represented by 10 blocks of remnant woodland, the largest of which is over 12,000 ha in size (Department of Conservation and Land Management 1995). Dryandra Woodland is characterised by woodland vegetation regimes dominated by Wandoo on the mid to lower slopes and low lying areas, and Powderbark Wandoo (E. accedens) on the gentle to steep upper slopes and along lateritic ridges. Mixed species associations with Marri (Corymbia calophylla), Jarrah (E. 
marginata) and Rock Sheoak (Allocasuarina huegeliana) also occur, as do kwongan shrublands dominated by Proteaceae and Mrytaceae species.

\section{Study sites}

We examined the relationship between habitat complexity and avian species richness in 48 sites of E. wandoo and E. accedens woodland throughout Dryandra Woodland. We undertook fieldwork between July and November 2001, a time corresponding with the breeding season of many of the resident species (pers. obs.). We selected sites with an array of habitat structural complexities, although sites were avoided if they were on the ecotone between woodland and other vegetation communities. This approach avoids complicating the interpretation of avian species presence through a grossly heterogeneous vegetation structure within sites.

\section{Habitat complexity}

At each site, we measured habitat complexity in a three hectare area using a modified form of the method developed by Newsome and Catling (1979). The normal method of assigning habitat complexity scores is based on subjective field estimates of percentage cover of various habitat components typically denoting cover as one of five measures of cover (complexity) between one and five (Catling and Burt 1995; Newsome and Catling 1979; Watson et al. 2001). However, in this study we assigned component scores following collection and subsequent examination of quantitative field data.

Within each site, we recorded canopy complexity from a measure of canopy cover; the percentage incidence of sapling, $(1 \mathrm{~m}-5 \mathrm{~m})$, subcanopy $(5 \mathrm{~m}-10 \mathrm{~m})$ and canopy $(>10 \mathrm{~m})$ trees recorded every $10 \mathrm{~m}$ along a $530 \mathrm{~m}$ transect traversing the site. We recorded shrub complexity from a measure of the mean shrub density at six equidistant points along the transect, calculated using the point-quarter method (Cottam and Curtis 1956). We measured 
ground vegetation (including any herbaceous and grassy vegetation typically $<0.3 \mathrm{~m}$ in height) and leaf litter (comprising leaf litter, twigs and bark) complexity from the mean cover within a $0.3 \mathrm{~m} \times 0.3 \mathrm{~m}$ quadrate, recorded at 15 equidistant points along the transect. We recorded log complexity from a measure of log density, calculated as the inverse of the mean distance to nearest log from 15 equidistant points along the transect.

To determine the score boundaries for each component, we ordered all data from each component and divided each into five approximately equal sized groups (representing the five score ranks for each component). We then altered the range boundaries to align them for each component score to the nearest major unit (see Table 1). This methodology is a more quantitative method for measuring habitat complexity by eliminating the subjectivity of traditional field-based estimates used in previous studies (e.g., Newsome and Catling 1979; Watson et al. 2001).

(Insert Table 1)

For each site, we calculated a habitat complexity score on the basis of five habitat attributes; canopy, shrub, ground vegetation, log and leaf litter cover (Table 1). Each component was rated on a scale of one to five (sparse to abundant), and then totaled to give an overall site habitat complexity score (Catling and Burt 1995; Watson et al. 2001). As such, site scores could range between five and 25. Overall habitat complexity scores under 10 typically represented sites with a low canopy cover and understorey cover of shrubs and ground vegetation, and a sparse amount of leaf litter and logs. Habitat complexity scores over 20 typically represented sites with a high canopy cover and abundant understorey and dense leaf litter and logs. While there is no assumption of equivalence in the increase in scores of one habitat complexity component to the next, there is a general assumption of an overall increase in general structural complexity of the habitat with the addition of scores from any or all 
individual habitat complexity components. In the examination of individual species responses to habitat complexity, those components contributing to overall habitat complexity were examined to assist in the interpretation of the overall habitat complexity response.

\section{Avian surveys}

Collection of quantitative field data took between 60 and 90 minutes to collect from each site. During this time, one author (JAC) recorded habitat data and simultaneously opportunistically recorded avian species presence while the other author (RDP) independently recorded avian species throughout the three hectare site. We recorded avian species by sight as well as by sound, but only if they were within the three hectare area. Species flying over sites were not included. Surveying was undertaken throughout the day except between 1100 and 1400, or if it was too windy, or raining. We only surveyed each site once for avian species. As the vegetation of the study sites was open woodland, we were confident that a single search by each author of at least 60 minutes would account for all present species (see Nix and Brooker 1978). The only vegetation strata presenting any potential hindrance to detectability was the canopy and shrub layers. However, in open eucalypt woodland, when canopy complexity increases, it is not through the formation of additional horizontal layers (as in rainforest), thus, there is no hindrance in detectability of canopy-dwelling species. Furthermore, almost all species inhabiting shrubs in the study area are exceptionally vocal (e.g., white-browed scrubwren (Rhipidura albiscapa), blue-breasted fairy-wren (Malurus pulcherrimus), inland thornbill (Acanthiza apicalis)). Given the long survey time in relatively open habitat, without any impenetrable vegetation to hinder detectability, we were confident that two independent observers were able to detect all species utilising the site. Ideally, repeat surveys would have been conducted at each site to reduce the chance of imperfect detection (see MacKenzie 2005; MacKenzie and Royle 2005 for discussion), however, we opted to maximize the number of sites surveyed rather undertaking repeat surveys. 
Analysis

As the data for habitat complexity were ordinal, we calculated Spearman rank correlation coefficients to test for a relationship between the overall habitat complexity score and avian species richness in the 48 sites. We also calculated Spearman rank correlation coefficients to test for relationships between the five individual habitat complexity components and avian species richness in the 48 sites.

To assess the importance of habitat complexity on individual species, we undertook binomial logistic regression analysis on account of the binomial nature of the dependent variable (species either present or absent). We then used these regression models to produce probability of occurrence values and graphs for those species showing a significant association with habitat complexity scores. All regression analysis was undertaken using the Minitab statistics package (Minitab Inc, 2000). There is much conjecture in the literature regarding the appropriateness of significance levels following multiple statistical tests. In the present study, we chose to retain the p-value at the 5\% level of significance (see Rice 1989 for discussion).

\section{Results}

Fifty-eight species of bird (Appendix 1) were recorded in the 48 sites. Avian species richness at each site ranged between five and 20 species (11.02 \pm 0.49 ; mean \pm S.E.), while habitat complexity scores ranged between nine and $22(14.96 \pm 0.38)$.

\section{Habitat complexity vs’ avian species richness}

There was no significant correlation $\left(r_{\mathrm{s}}=0.204, \mathrm{df}=46 ; \mathrm{p}=0.134\right)$ between habitat complexity score and avian species richness in the 48 sites (Fig. 1). However, examining each of the habitat complexity components separately indicated a significant positive correlation of 
species richness with log complexity $\left(r_{s}=0.350, d f=46 ; p=0.011\right)$ and ground vegetation complexity $\left(r_{s}=0.295, d f=46 ; p=0.028\right)$. There was no significant correlation between species richness and canopy complexity $\left(r_{s}=0.107, d f=46 ; p=0.726\right)$, shrub complexity $\left(r_{s}\right.$ $=-0.001, \mathrm{df}=46 ; \mathrm{p}=0.803)$, or leaf litter complexity $\left(\mathrm{r}_{\mathrm{s}}=-0.257, \mathrm{df}=46 ; \mathrm{p}=0.147\right)$.

(Insert Figure 1)

Relationship of habitat complexity with individual species

For the logistic regression analysis, we eliminated 25 species of bird from the analysis that were recorded in fewer than five sites (see Vittinghoff and McCulloch 2007 for discussion on presence power)(see Appendix 1). Logistic regression models for three of the species showed significant lack of fit according to at least one of Pearson's chi-square, deviance or HosmerLemeshow goodness-of-fit tests (Appendix 1). Of the remaining 30 species, the presence of only two species was significantly related to habitat complexity at the $5 \%$ level of significance. The restless flycatcher (Myiagra inquieta) occupied significantly less structurally complex habitats (Table 2), while the western yellow robin (Eopsaltria griseogularis) occupied significantly more structurally complex habitats (Table 3). For purely exploratory means, if a less stringent estimate of level of significance is examined ( $\mathrm{p}<0.1$ ), the elegant parrot (Neophema elegans), rufous treecreeper (Climacteris rufa) and yellowplumed honeyeater (Lichenostomus ornatus) occupied structurally less complex habitats (Table 2), while the red-capped robin (Petroica goodenovii), striated pardalote (Pardalotus striatus) and white-naped honeyeater (Melithreptus lunatus) occupied more structurally complex habitats (Table 3).

(Insert Tables 2 and 3) 
We calculated cumulative probability values for all species with a significance value of $\mathrm{p}<$ 0.1 at three habitat complexity scores from the binary logistic regression analysis (Table 4). At an intermediate habitat complexity score of 15 , the mean probability of occurrence of the high habitat complexity selective species (from Table 4) was $36.5 \%$, compared to $35.8 \%$ for the low habitat complexity selective species.

(Insert Table 4)

Cumulative probability graphs (Fig. 2) for the restless flycatcher and western yellow robin showing relationship with habitat complexity scores (from Tables 2 and 3) indicated that to have a 50\% probability of a restless flycatcher occupying a site required sites with a maximum habitat complexity score of 9.5 , while having a $50 \%$ probability of a western yellow robin occupying a site required sites with a minimum habitat complexity score of 16.2.

(Insert Figure 2)

\section{Discussion}

Species richness and habitat complexity

We found no significant correlation between habitat complexity and species richness. A large body of literature suggests that with an increase in structural complexity of the habitat comes an increase in avian species diversity and richness (Hulbert 2004; MacArthur and MacArthur 1961; MacArthur et al. 1962; Willson 1974). This pattern is normally attributed to an assumption of greater availability of microhabitats and resources in vegetation with greater structural complexity.

Comparison with other studies of the effect of habitat complexity on avian communities, suggests that the scale of investigation is an important determinant of the relationship between 
species richness and structural complexity. Some studies suggest structural complexity is a good determinant of species richness at the landscape scale (Arnold 1988; Mac Nally 1990; Rotenberry 1985; Wiens and Rotenberry 1981) rather than the territory scale of the present study. Similarly, early studies examining the relationship of habitat structure with avian species diversity focused on comparisons between disparate ecosystem types (e.g., comparing grasslands to savannah to rainforest) and revealed that structurally more complex ecosystems were more diverse. As such, the likelihood of detecting a relationship of species richness and habitat complexity in the present study was reduced, given the comparatively subtle variations in structural complexity within the open woodland ecosystem sampled in the present study.

Alternatively, we postulate that the absence of a species richness relationship with habitat complexity may stem from the resource-limited environment characteristic of the woodland ecosystems in south-western Australia. Studies examining the relationship of habitat complexity with species richness in Australia have primarily been undertaken in more productive forests of the southeast of Australia (e.g. Nix and Brooker 1978; Watson et al. 2003). Braithwaite et al. (1989) found that avian species richness was higher in those southeast forests with a greater tree basal area (an index of total biomass akin to structural complexity) and foliar magnesium. As a result of lower foliar nutrients (Majer et al. 1992) and invertebrate biomass (Majer et al. 1999; Majer et al. 1990) associated with Western Australian Eucalyptus trees compared to eastern Australian trees, an increase in structural complexity of the vegetation may not necessarily reflect additional microhabitats and resources for more species. Thus, the higher species richness response present in southeast Australian forests may be influenced by the increased productivity in more structurally complex habitats, rather than structural complexity per se. It may suggest that in the present study area, there is a species richness threshold beyond which there are insufficient resources for additional species. While greater habitat complexity intuitively implies a larger number of 
foraging niches, an absence of a relationship between habitat complexity and species richness may indicate that species broaden their foraging niches. For example, Recher and Davis (1998) indicated that birds in wandoo woodland broadened their foraging over a wider range of substrates than their eastern Australian counterparts.

\section{Species richness and individual habitat complexity components}

The presence of a significant positive correlation between avian species richness and log density and ground vegetation cover supports results from other studies. Laven and MacNally (1998) found that the abundance and species richness of birds was significantly higher in sites with a higher abundance of logs. Logs provide abundant invertebrate prey habitat that large numbers of avian species such as the robins and treecreepers utilise as a foraging resource (Cousin 2004b; Laven and Mac Nally 1998; Recher 1991). Similarly, the significant positive correlation of avian species richness with ground vegetation can be explained by the elevated diversity of invertebrate communities in a structurally diverse and complex ground vegetation (Bromham et al. 1999). The absence of a relationship between species richness and canopy complexity stems from the fact that an increase in canopy complexity in the open woodland of the present study area does not necessarily reflect formation of additional horizontal layers and thus an increase in available microhabitats.

\section{Individual species response to habitat complexity}

Although there was no relationship between species richness and habitat complexity, a number of individual species did exhibit clear associations with habitat complexity. The present study is the first to demonstrate a specific habitat complexity response by the western yellow robin. Occupation of sites with a high habitat complexity by western yellow robins reflects the selection by this species for habitat with high understorey complexity, particularly comprising a rich litter layer and dense coarse woody debris (Higgins and Peter 2002), and 
selection for habitat with a dense canopy cover (Cousin 2004a). These factors relate to the selection of sites with abundant understorey invertebrate prey habitat, an important foraging resource of the ground foraging western yellow robin (Cousin 2004b). Occupation by the restless flycatcher of sites with lower habitat complexity reflects the selection by this species for open woodland sites (Boles 1988). Although classed as an arboreal forager (Boles 1988), in southwestern Australia the restless flycatcher is primarily an aerial forager (Recher and Davis 1998). Occupation of sites with a low understorey complexity assists in the foraging behaviour of this species, which often hovers and scans for prey above open ground. Interestingly, in a study by Watson et al. (2001), the restless flycatcher exhibited a habitat complexity response by occupying more complex sites, although their results reflected a combination of remnant size and habitat complexity and the primarily arboreal foraging behaviour of this species in eastern Australia.

\section{Conclusion}

Although some species may respond predictably to habitat with specific structural properties, the results of the present study suggest that conservation management plans should not focus too heavily on the accepted doctrine of 'greater habitat complexity will result in greater species richness'. Indeed, only one species in the present study, the Western Yellow Robin, responded favourably to greater overall habitat complexity. Instead, management of avian biodiversity within Australian woodlands should take into account the potentially greater role that productivity and resource availability plays in influencing species richness. Furthermore, the results of the present study also suggest the importance of examining the role of individual structural components comprising habitat complexity, as these may be of equal importance in assessing the relationship of species richness with habitat complexity. 


\section{Acknowledgements}

We would like to thank Dr Stuart Cairns from the University of New England (UNE) for help in statistical analysis. Birds Australia provided financial assistance through the Stuart Leslie Bird Research Award, as did the Centre for Ecosystem Management at Edith Cowan University. Thank you also to Prof Hugh Ford (UNE), Dr Veronica Doerr (CSIRO, Canberra) and three anonymous reviewers for comments on earlier versions of the manuscript. 


\section{References}

Ammon E. M. and Stacey P. B. (1997). Avian nest success in relation to past grazing regimes in a montane riparian system. Condor 99, 7 - 13.

Arnold G. W. (1988). The effects of habitat structure and floristics on the densities of bird species in Wandoo woodland. Australian Wildlife Research 15, 499 - 510.

Boles W. E. (1988). 'The Robins and Flycatchers of Australia.' (Angus\&Robertson: North Ryde, NSW.)

Braithwaite L. W., Austin M. P., Clayton M., Turner J. and Nicholls A. O. (1989). On predicting the presence of birds in Eucalyptus forest types. Biological Conservation 50, 33 50.

Bromham L., Cardillo M., Bennett A. F. and Elgar M. A. (1999). Effects of stock grazing on the ground invertebrate fauna of woodland remnants. Australian Journal of Ecology 24, 199 207.

Catling P. C. and Burt R. J. (1995). Studies of the ground-dwelling mammals of eucalypt forests in south-eastern New South Wales: the effect of habitat variables on distribution and abundance. Wildlife Research 22, 271 - 278.

Coates A. (1993). 'Vegetation Survey of Dryandra Forest.' (Department of Conservation and Land Management: Perth.)

Coops N. C. and Catling P. C. (2000). Estimating forest complexity in relation to time since fire. Austral Ecology 25, 344 - 351.

Cottam G. and Curtis D. J. (1956). The use of distance measures in phytosociological sampling. Ecology 37, 451 - 460.

Cousin J. A. (2004a). Habitat selection of the Western Yellow Robin (Eopsaltria griseogularis) in a Wandoo woodland, Western Australia. Emu 104, 229 - 234. 
Cousin J. A. (2004b). Pounce site characteristics of the Western Yellow Robin Eopsaltria griseogularis: the importance of assessing foraging microhabitat. Pacific Conservation Biology 10, 21 - 27.

Department of Conservation and Land Management (1995). 'Dryandra Woodland Management Plan 1995 - 2005.' Lands and Forest Commission, Perth.

Ford H. A., Barrett G. W., Saunders D. A. and Recher H. F. (2001). Why have birds in the woodlands of Southern Australia declined? Biological Conservation 97, 71 - 88.

Hauser A., Attrill M. J. and Cotton P. A. (2006). Effects of habitat complexity on the diversity and abundance of macrofauna colonising artificial kelp holdfasts. Marine Ecology - Progress Series 325, 93 - 100.

Higgins P. J. and Peter J. M. (Eds) (2002). 'Handbook of Australian, New Zealand and Antarctic Birds. Volume 6. Pardalotes to Spangled Drongo.' (Oxford University Press: Melbourne.)

Hildén O. (1965). Habitat selection in birds: a review. Annales Zoologici Fennici 2, 54 - 75. Hulbert A. H. (2004). Species-energy relationships and habitat complexity in bird communities. Ecology Letters 7, 714 - 720.

Lassau S. A. and Hochuli D. F. (2005). Wasp community responses to habitat complexity in Sydney sandstone forests. Austral Ecology 30, 179 - 187.

Laven N. H. and Mac Nally R. (1998). Association of birds with fallen timber in box-ironbark forest of central Victoria. Corella 22, 56 - 60.

Lingo M. E. and Szedlmayer S. T. (2006). The influence of habitat complexity on reef fish communities in the northeastern Gulf of Mexico. Environmental Biology of Fishes 76, 71 80.

Ludwig J. A., Eager R. W., Liedloff A. C., McCosker J. C., Hannah D., Thurgate N. Y., Woinarski J. C. Z. and Catterall C. P. (2000). Clearing and grazing impacts on vegetation 
patch structures and fauna counts in eucalypt woodland, central Queensland. Pacific Conservation Biology 6, 254 - 272.

Mac Nally R. C. (1990). The roles of floristics and physiognomy in avian community composition. Australian Journal of Ecology 15, 321 - 327.

MacArthur R. H. and MacArthur J. W. (1961). On bird species diversity. Ecology 42, 594 598.

MacArthur R. H., MacArthur J. W. and Preer J. (1962). On bird species diversity. II. Prediction of bird census from habitat measurements. The American Naturalist 96, 167 - 174. MacKenzie D. I. (2005). Was it there? Dealing with imperfect detection for species presence/absence data. Australian and New Zealand Journal of Statistics 47, 65 - 74. MacKenzie D. I. and Royle J. A. (2005). Designing occupancy studies: general advice and allocating survey effort. Journal of Applied Ecology 42, 1105 - 1114.

Majer J. D., Recher H. and Keals N. (1999). Canopy arthropod faunas in fragmented agricultural landscapes. In 'Temperate Eucalypt Woodlands in Australia: Biology, Conservation, Management and Restoration'. (Eds R. J. Hobbs and C. J. Yates) pp. 235 - 247. (Surrey Beatty \& Sons: Chipping Norton.)

Majer J. D., Recher H. F. and Ganeshanandam S. (1992). Variation in foliar nutrients in Eucalyptus trees in eastern and western Australia. Australian Journal of Ecology 17, 383 393.

Majer J. D., Recher H. F., Perriman W. S. and Achuthan N. (1990). Spatial variation of invertebrate abundance within the canopies of two Australian eucalypt forests. Studies in Avian Biology 13, 65 - 72.

Minitab I. (2000). 'MINITAB.' version 13.0. (Minitab Inc.: State College, Pennsylvania, USA.)

Newsome A. E. and Catling P. C. (1979). Habitat preferences of mammals inhabiting heathlands of warm temperate coastal, montane and alpine regions of southeastern Australia. 
In 'Heathlands and related shrublands of the world: descriptive studies'. (Ed. R. L. Specht) pp. 301 - 316. (Elsevier: Amsterdam.)

Nix H. A. and Brooker M. G. (1978). Part 3: Birds. In 'Land Use on the South Coast of New South Wales: A Study in Methods of Acquiring and Using Information to Analyse Regional Land Use Options'. (Eds M. P. Austin and K. D. Cocks) pp. 74 - 80. (CSIRO: Melbourne.) Recher H. F. (1991). The conservation and management of eucalypt forest birds: resource requirements for nesting and foraging. In 'Conservation of Australia's Forest Fauna'. (Ed. D. Lunney) pp. 25 - 34. (Royal Zoological Society of NSW: Mosman.)

Recher H. F. and Davis W. E. (1998). The foraging profile of a wandoo woodland avifauna in early spring. Australian Journal of Ecology 23, 514 - 527.

Rice W. R. (1989). Analyzing tables of statistical tests. Evolution 43, 223 - 225.

Rotenberry J. T. (1985). The role of habitat in avian community composition: physiognomy or floristics. Oecologia 67, 213 - 217.

Saunders D. A. and Curry P. J. (1990). The impact of agricultural and pastoral industries on birds in the southern half of Western Australia: past, present and future. Proceedings of the Ecological Society of Australia 16, 303 - 321.

Saunders D. A. and Ingram J. (1995). 'Birds of southwestern Australia; an atlas of changes in distribution and abundance of the wheatbelt fauna.' (Surrey Beatty \& Sons Pty Ltd.: Chipping Norton, NSW.)

Saunders D. A., Rowley I. and Smith G. T. (1985). The effects of clearing for agriculture on the distribution of cockatoos in the southwest of Western Australia. In 'Birds of Eucalypt Forests and Woodlands: Ecology, Conservation, Management'. (Eds A. Keast, H. F. Recher, H. Ford and D. Saunders) pp. 309 - 321. (Royal Australasian Ornithologists Union and Surrey Beatty \& Sons: Chipping Norton, NSW.)

Vittinghoff E. and McCulloch C. E. (2007). Relaxing the rule of ten events per variable in logistic and Cox regression. American Journal of Epidemiology 165, 710 - 718. 
Watson J., Freudenberger D. and Paull D. (2001). An assessment of the focal-species approach for conserving birds in variegated landscapes in southeastern Australia.

Conservation Biology 15, 1364 - 1373.

Watson J., Watson A., Paull D. and Freudenberger D. (2003). Woodland fragmentation is causing the decline of species and functional groups of birds in southeastern Australia. Pacific Conservation Biology 8, 261 - 270.

Watson J. E. M., Whittaker R. J. and Dawson T. P. (2004). Habitat structure and proximity to forest edge affect the abundance and distribution of forest-dependent birds in tropical coastal forests of southern Madagascar. Biological Conservation 120, 311 - 327.

Wiens J. A. and Rotenberry J. T. (1981). Habitat associations and community structure of birds in shrubsteppe environments. Ecological Monographs 51, 21 - 41.

Willett T. R. (2001). Spiders and other arthropods as indicators in old-growth versus logged redwood stands. Restoration Ecology 9, 410 - 420.

Williams R. J. (1990). Cattle grazing within subalpine heathland and grassland communities in the Bogong High Plains: disturbance, regeneration and the shrub-grass balance.

Proceedings of the Ecological Society of Australia 16, 255 - 265.

Willson M. F. (1974). Avian community organization and habitat structure. Ecology 55, 1017 $-1029$. 
Table 1: The individual components of the habitat complexity score and their rating boundaries.

Canopy refers to percentage incidence of sapling, subcanopy and canopy trees. Shrubs refers to shrubs per hectare. Ground vegetation refers to percentage cover of herbaceous and grassy vegetation on the ground. Logs refer to mean distance from sampling points to logs. Leaf litter refers to percentage cover of leaf litter, twigs and bark on the ground.

\begin{tabular}{|c|c|c|c|c|c|}
\hline \multirow[b]{2}{*}{ Components } & \multicolumn{5}{|c|}{ Habitat complexity score } \\
\hline & 1 & 2 & 3 & 4 & 5 \\
\hline Canopy & $<20 \%$ & $20-30 \%$ & $30-40 \%$ & $40-50 \%$ & $>50 \%$ \\
\hline Shrubs & $<500$ & $500-1000$ & $1000-2000$ & $2000-5000$ & $>5000$ \\
\hline Ground vegetation & $<5 \%$ & $5-10 \%$ & $10-20 \%$ & $20-30 \%$ & $>30 \%$ \\
\hline Logs & $>7 \mathrm{~m}$ & $6-7 m$ & $5-6 m$ & $4-5 m$ & $<4 \mathrm{~m}$ \\
\hline Leaf litter & $<50 \%$ & $50-60 \%$ & $60-70 \%$ & $70-80 \%$ & $>80 \%$ \\
\hline
\end{tabular}


Table 2: Negative relationships between bird-species presence and habitat complexity according to binomial logistic regression analysis.

Analysis includes all species found in at least five sites. ' $\beta$ ' refers to regression co-efficient, ' $n$ ' refers to number of sites (out of 48) in which the species was recorded. 95\% CI refers to the lower and upper bounds of the 95\% confidence interval of the odds ratio. * significant at p $<0.05$.

\begin{tabular}{llllllll}
\hline & & & & & $95 \%$ CI \\
Species & $\beta$ & $n$ & $p$ & Odds ratio & Lower & Upper \\
\hline Australian ringneck & -0.0236 & 34 & 0.847 & 0.98 & 0.77 & 1.24 \\
Brown honeyeater & -0.0487 & 10 & 0.724 & 0.95 & 0.73 & 1.25 \\
Dusky woodswallow & -0.2021 & 12 & 0.149 & 0.82 & 0.62 & 1.07 \\
Elegant parrot & -0.2854 & 12 & 0.056 & 0.75 & 0.56 & 1.01 \\
Restless flycatcher & -0.3835 & 7 & $0.038 *$ & 0.68 & 0.47 & 0.98 \\
Rufous treecreeper & -0.2351 & 28 & 0.071 & 0.79 & 0.61 & 1.02 \\
Scarlet robin & -0.0745 & 9 & 0.607 & 0.93 & 0.70 & 1.23 \\
Tree martin & -0.0545 & 13 & 0.666 & 0.95 & 0.74 & 1.21 \\
Yellow-plumed honeyeater & -0.2318 & 24 & 0.072 & 0.79 & 0.62 & 1.02 \\
\hline
\end{tabular}


Table 3: Positive relationships between bird-species presence and habitat complexity according to binomial logistic regression analysis.

Analysis includes all species found in at least five sites. ' $\beta$ ' refers to regression co-efficient, ' $n$ ' refers to number of sites (out of 48) in which the species was recorded. 95\% CI refers to the lower and upper bounds of the 95\% confidence interval of the odds ratio. * significant at p $<0.05$.

\begin{tabular}{|c|c|c|c|c|c|c|}
\hline \multirow[b]{2}{*}{ Species } & \multirow[b]{2}{*}{$\beta$} & \multirow[b]{2}{*}{$\mathrm{n}$} & \multirow[b]{2}{*}{$p$} & \multirow[b]{2}{*}{ Odds ratio } & \multicolumn{2}{|c|}{$95 \% \mathrm{CI}$} \\
\hline & & & & & Lower & Upper \\
\hline Australian raven & 0.0087 & 14 & 0.943 & 1.01 & 0.79 & 1.28 \\
\hline Black-faced cuckoo-shrike & 0.0398 & 5 & 0.826 & 1.04 & 0.73 & 1.48 \\
\hline Brown-headed honeyeater & 0.0319 & 7 & 0.839 & 1.03 & 0.76 & 1.40 \\
\hline Fan-tailed cuckoo & 0.207 & 7 & 0.201 & 1.23 & 0.90 & 1.69 \\
\hline Golden whistler & 0.1527 & 13 & 0.242 & 1.16 & 0.90 & 1.50 \\
\hline Grey fantail & 0.0430 & 30 & 0.710 & 1.04 & 0.83 & 1.31 \\
\hline Grey shrike-thrush & 0.0363 & 22 & 0.745 & 1.04 & 0.83 & 1.29 \\
\hline Inland thornbill & 0.1358 & 13 & 0.293 & 1.15 & 0.89 & 1.48 \\
\hline Red wattlebird & 0.0885 & 9 & 0.535 & 1.09 & 0.83 & 1.45 \\
\hline Red-capped parrot & 0.0254 & 11 & 0.847 & 1.03 & 0.79 & 1.33 \\
\hline Red-capped robin & 0.3267 & 6 & 0.071 & 1.39 & 0.97 & 1.98 \\
\hline Silvereye & 0.2388 & 9 & 0.118 & 1.27 & 0.94 & 1.71 \\
\hline Striated pardalote & 0.2483 & 35 & 0.080 & 1.28 & 0.97 & 1.69 \\
\hline Varied sitella & 0.0247 & 12 & 0.847 & 1.02 & 0.80 & 1.32 \\
\hline Weebill & 0.0298 & 38 & 0.828 & 1.03 & 0.79 & 1.35 \\
\hline Western gerygone & 0.1728 & 33 & 0.182 & 1.19 & 0.92 & 1.53 \\
\hline Western spinebill & 0.2159 & 9 & 0.151 & 1.24 & 0.92 & 1.67 \\
\hline
\end{tabular}




\begin{tabular}{lcccccc} 
Western thornbill & 0.1031 & 13 & 0.417 & 1.11 & 0.86 & 1.42 \\
Western yellow robin & 0.4087 & 19 & $0.013^{*}$ & 1.50 & 1.09 & 2.08 \\
White-browed scrubwren & 0.1031 & 13 & 0.417 & 1.11 & 0.86 & 1.42 \\
White-naped honeyeater & 0.2774 & 12 & 0.060 & 1.32 & 0.99 & 1.76 \\
\hline
\end{tabular}


Table 4: Percent probability of occurrence of various species in sites with differing habitat complexity scores (HCS).

Species included are those with a binary logistic regression p-value less than 0.1 . Species are ordered in ascending p-value scores from Tables 2 and 3.

\begin{tabular}{llll}
\hline Species & HCS 8 & HCS 15 & HCS 22 \\
\hline Western yellow robin & 3 & 38 & 92 \\
Restless flycatcher & 64 & 11 & 1 \\
Elegant parrot & 68 & 23 & 4 \\
White-naped honeyeater & 4 & 23 & 68 \\
Red-capped robin & 1 & 10 & 53 \\
Rufous treecreeper & 88 & 59 & 22 \\
Yellow-plumed honeyeater & 83 & 50 & 16 \\
Striated pardalote & 34 & 75 & 94 \\
\hline
\end{tabular}


Figure 1: Relationship of total habitat complexity score to bird species richness in 48 sites.

Please note that there are only 39 points in the figure, as a result of double-ups in sites with identical habitat complexity scores and species richness.

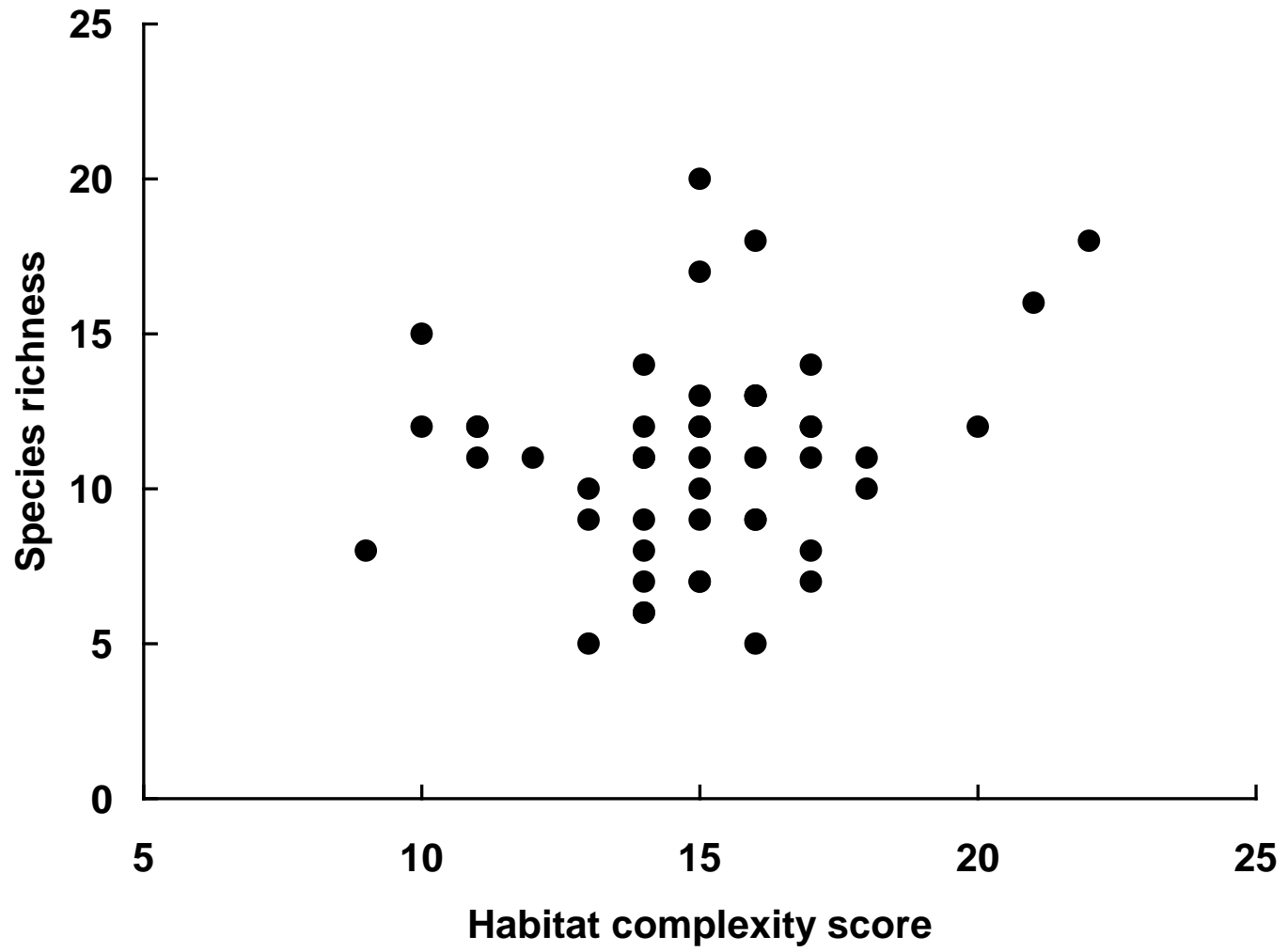


Figure 2: Cumulative probability graph for the restless flycatcher (bold line) and the western yellow robin (dashed line) as a function of habitat complexity score.

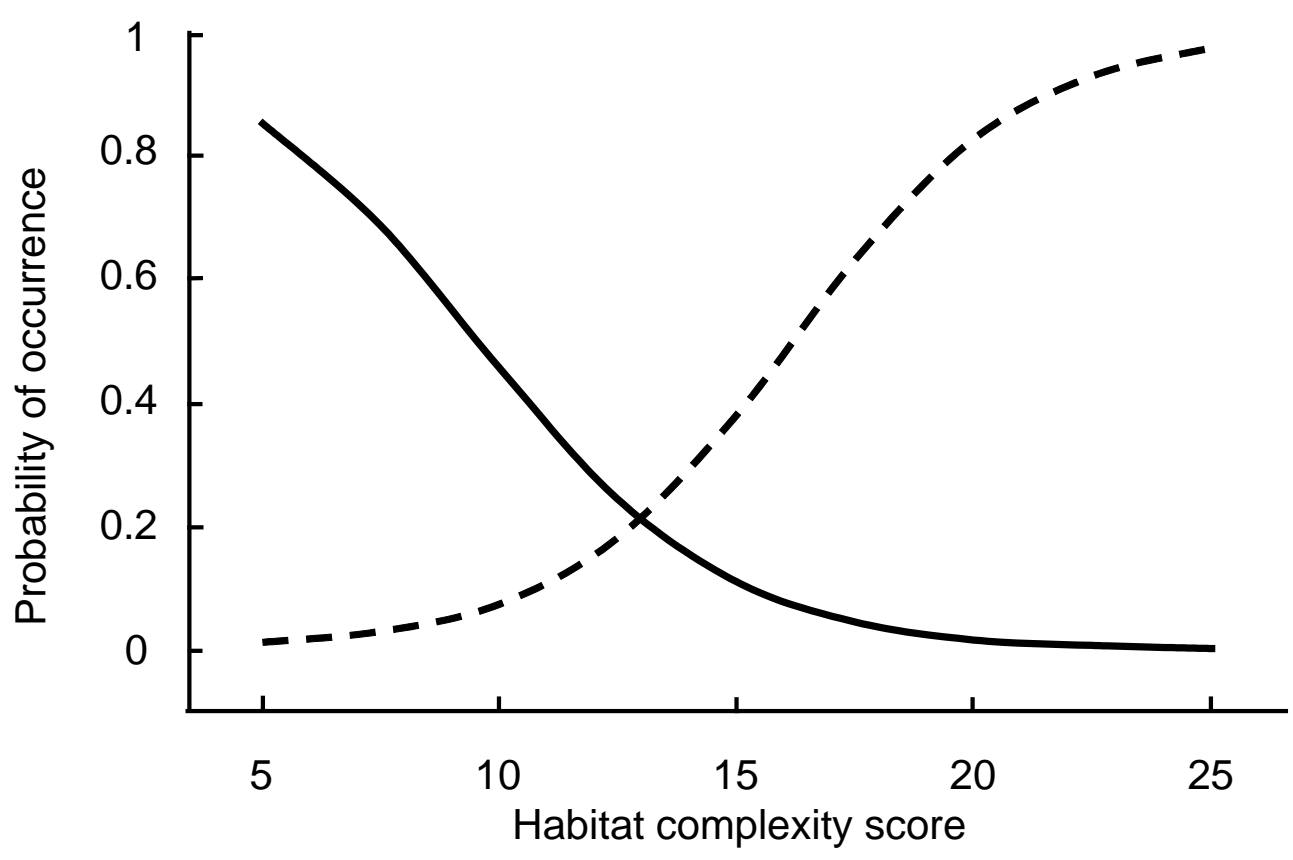




\section{Appendix 1: Alphabetical list of common and scientific names of birds observed during}

\section{the study.}

* species recorded at less than five sites

${ }^{\dagger}$ species eliminated as a result of significant lack of fit of logistic regression model

\begin{tabular}{|c|c|c|c|}
\hline Australian magpie * & Gymnorhina tibicen & Restless flycatcher & Myiagra inquieta \\
\hline Australian raven & Corvus coronoides & Rufous treecreeper & Climacteris rufa \\
\hline Australian ringneck & Barnardius zonarius & Rufous whistler * & Pachycephala rufiventris \\
\hline Australian shelduck * & Tadorna tadornoides & Scarlet robin & Petroica boodang \\
\hline Black-faced cuckoo-shrike & Coracina novaehollandiae & Shining bronze-cuckoo * & Chalcites lucidus \\
\hline Blue-breasted fairy- wren $†$ & Malurus pulcherrimus & Silvereye & Zosterops lateralis \\
\hline Brown goshawk * & Accipiter fasciatus & Singing honeyeater * & Lichenostomus virescens \\
\hline Brown honeyeater & Lichmera indistincta & Striated pardalote & Pardalotus striatus \\
\hline Brown-headed honeyeater & Melithreptus brevirostris & Tawny-crowned honeyeater * & Phylidonyris melanops \\
\hline Carnaby’s cockatoo * & Calyptorhynchus latirostris & Tree martin & Petrochelidon nigricans \\
\hline Common bronzewing $\dagger$ & Phaps chalcoptera & Varied sitella & Daphoenositta chrysoptera \\
\hline Dusky woodswallow & Artamus cyanopterus & Weebill & Smicrornis brevirostris \\
\hline Elegant parrot & Neophema elegans & Welcome swallow * & Hirundo neoxena \\
\hline Fan-tailed cuckoo & Cacomantis flabelliformis & Western gerygone & Gerygone fusca \\
\hline Golden whistler & Pachycephala pectoralis & Western rosella * & Platycercus icterotis \\
\hline Grey currawong † & Strepera versicolor & Western shrike-tit * & Falcunculus leucogaster \\
\hline Grey fantail & Rhipidura albiscapa & Western spinebill & Acanthorhynchus superciliosus \\
\hline Grey shrike-thrush & Colluricincla harmonica & Western thornbill & Acanthiza inornata \\
\hline Hooded robin $*$ & Melanodryas cucullata & Western wattlebird * & Anthochaera lunulata \\
\hline Horsefield’s bronze-cuckoo * & Chalcites basalis & Western yellow robin & Eopsaltria griseogularis \\
\hline Inland thornbill & Acanthiza apicalis & Whistling kite * & Haliastur sphenurus \\
\hline Laughing kookaburra * & Dacelo novaeguineae & White-browed babbler * & Pomatostomus superciliosus \\
\hline New Holland honeyeater * & Phylidonyris novaehollandiae & White-browed scrubwren & Sericornis frontalis \\
\hline Painted button-quail * & Turnix varia & White-eared honeyeater * & Lichenostomus leucotis \\
\hline Purple-crowned lorikeet * & Glossopsitta porphyrocephala & White-naped honeyeater & Melithreptus lunatus \\
\hline Rainbow bee-eater * & Merops ornatus & White-winged triller * & Lalage tricolor \\
\hline Red wattlebird & Anthochaera carunculata & Willie wagtail * & Rhipidura leucophrys \\
\hline Red-capped parrot & Purpureicephalus spurius & Yellow-plumed honeyeater & Lichenostomus ornatus \\
\hline Red-capped robin & Petroica goodenovii & Yellow-rumped thornbill * & Acanthiza chrysorrhoa \\
\hline
\end{tabular}

